NBER WORKING PAPER SERIES

\title{
GLOBALIZATION, GROWTH AND CRISES: \\ THE VIEW FROM LATIN AMERICA
}

\author{
Sebastian Edwards \\ Working Paper 14034 \\ http://www.nber.org/papers/w14034

\section{NATIONAL BUREAU OF ECONOMIC RESEARCH \\ 1050 Massachusetts Avenue \\ Cambridge, MA 02138}

May 2008

This is a revised version of the 2007 Corden Lecture, in honor of W. Max Corden, which I delivered at the University of Melbourne on October 11th 2007. I thank Alberto Naudon for his assistance and comments. The views expressed herein are those of the author(s) and do not necessarily reflect the views of the National Bureau of Economic Research.

NBER working papers are circulated for discussion and comment purposes. They have not been peerreviewed or been subject to the review by the NBER Board of Directors that accompanies official NBER publications.

(C) 2008 by Sebastian Edwards. All rights reserved. Short sections of text, not to exceed two paragraphs, may be quoted without explicit permission provided that full credit, including $\odot$ notice, is given to the source. 
Globalization, Growth and Crises: The View from Latin America

Sebastian Edwards

NBER Working Paper No. 14034

May 2008

JEL No. F21,F30,F32,N26,O40

\begin{abstract}
In this paper I analyze the role of openness and globalization in Latin America's economic development. The paper is divided into two distinct part: I first (Sections II through IV) provide an analysis of 60 years of the region's economic history, that go form the launching of the Alliance for Progress by the Kennedy Administration in 1961, to the formulation and implementation of the market-oriented reforms of the Washington Consensus in the 1990s and 2000s. I conclude that Latin America's history has been characterized by low growth, high inflation and recurrent external crises. In Section V I deal formally with the costs of crises, and I estimate a number of variance component models of the dynamics of growth. I find that external crises have been more costly in Latin America than in the rest of the world. I also find that the cost of external crises has been inversely related to the degree of openness.
\end{abstract}

Sebastian Edwards

UCLA Anderson Graduate School of Business

110 Westwood Plaza, Suite C508

Box 951481

Los Angeles, CA 90095-1481

and NBER

sebastian.edwards@anderson.ucla.edu 


\section{Introduction}

During the last few years there has been an increasing anti-globalization sentiment among politicians and the public at large in a number of countries. Some authors have argued that globalization has gone too far and that the relaxation of barriers to international trade and capital movement has increased vulnerability and income inequality. Stiglitz (2002), for instance, has argued that globalization policies and market oriented reforms have the potential of doing a lot of good, if undertaken properly. According to him, however, globalization has not been pushed carefully or fairly. On the contrary, in his view, during the 1990s and early 2000s liberalization policies were implemented too fast, in the wrong order, and often using inadequate - or plainly wrong - economic analysis.

Criticism of globalization has been particularly strong in Latin America, where in recent years a number of leaders from the left have been elected presidents. Hugo Chávez of Venezuela is the most outspoken of them, but he is not the only one. Other that are (or have been) equally critical of globalization, market orientation and the "Washington Consensus” include Nestor Kirshner of Argentina, Evo Morales of Bolivia, Rafael Correa of Ecuador, and Daniel Ortega of Nicaragua. Many governments in Latin America have announced the nationalization of foreign investments, have imposed price controls, and have partially undone the opening of their economies by increasing import duties, export taxes and other forms of trade barriers.

In this paper I analyze Latin America’s experience with economic reform during the last twenty years, and I ask why the pro-markets and globalization policies of the "Washington Consensus” have become increasingly unpopular in the region. The main conclusions of this analysis are two:

o First, the successive currency crises that affected Latin America during the 1990s and first half of the 2000s were extremely costly. The best known of these are the Mexican crisis of 1994-95, the Brazilian crisis of 1999, the Argentine crisis of 2001-02 and the Uruguayan crisis of 2002. Voters in most countries associated these episodes with market-reform and the opening up of their economies. Understandably, this resulted in a 
significant decline in the political support for so-called "neo-liberal" policies.

o Second, recent macroeconomics reforms - and, in particular, the reduction of fiscal and external deficits, and the adoption of flexible exchange rates - have greatly reduced the probability of major currency crises in the future. This is good news. This doesn't necessarily mean, however, that in the years to come there will be an increase in the degree of support for globalization or market reforms in Latin America. In fact, it is highly likely that Latin America will continue to lag other regions in terms of openness, strength of institutions, and competition policies.

Long term growth has been disappointingly low in Latin America. Between 1970 and 2006 income per capita grew at an average of merely 1\% per year. Compare this to 2.3\% per capita growth in the advanced countries, 3\% in Asia, and 3\% in the Middle East and Northern Africa. ${ }^{1}$ Only Sub-Saharan Africa, with a rate of economic expansion that averaged $0.9 \%$, did worse than Latin America.

Historically, social conditions have also been poor in Latin America. For decades the number of people living below the poverty line has been very high and income distribution extremely unequal. Indeed, some of the highest Gini coefficients ever recorded in the world correspond to Brazil and Panama. ${ }^{2}$ Even Chile, Latin America's most successful economy during the last 20 years, continues to have a very unequal distribution of income. It is not an exaggeration to say that Latin America's modern economic history has been one of modest growth, macroeconomic crises, inequality, and poverty.

In 2004-2007, and partially as a result of higher commodity prices, Latin America experienced a growth revival -- real per capita GDP growth averaged an impressive 3.15\%. This faster growth has been accompanied by lower external deficits, declining

\footnotetext{
${ }^{1}$ These numbers for "Latin America" refer to Latin America proper and exclude the Caribbean countries. When these are included, however, the resulting rate of growth is somewhat higher, but the overall message does not change. The Asian data refer to all of Asia. If the analysis is restricted to the so-called "Asian Tigers", the contrast with Latin America is even more marked.

${ }^{2}$ See, for example, the essays in Edwards (2007b), especially Prados de la Escosura (2007). See, also, World Bank (2003).
} 
debts, and relatively low and stable inflation. As a result of this, a number of questions regarding the region's future have emerged: Will this acceleration of growth be sustained? Will Latin America experience a social take-off, with significant reductions in poverty and inequality? Will the Latin American countries avoid the type of macroeconomic crises that have frequently affected them in the past? Or will this be another short term spur in growth that, at the end of the road, will not amount to a sustained improvement in economic conditions?

The rest of the paper is organized as follows: In Section II I analyze the most salient aspects of Latin America's economic history during the 1940-1982 period. The discussion deals with the Kennedy Administration's Alliance for Progress, the debt crisis of the 1980s, and the "lost decade.” In Section III I concentrate on the 1990s and the reforms of the so-called Washington Consensus. In Section IV I focus on the succession of macroeconomic and external crises that affected a number of Latin American countries in between 1994-2002. In Section V I deal with the cost of crises in greater detail, and I report results from the estimation of a number of variance component models that capture the effect of external shocks and disturbances on the dynamics of growth. Finally, in Section VI I raise some questions regarding Latin America's future and I provide some concluding remarks.

Throughout the paper I point out those aspects of Latin America's economic history that today are better understood thanks to Max Corden’s many contributions to economic analysis. What is particularly interesting is that from early on Corden's work, which was motivated by economic challenges faced by Australia, was highly relevant for understanding the travails of the Latin American nations. I also show that much of the work undertaken by Corden in the 1980s and 1990s were - and, for that matter, continue to be -- extremely relevant for Latin America.

\section{From Protectionism to the Debt Crisis of 1982: Fifty Years of Latin} America's Economic History

In this Section I analyze 20 years of the region's economic history, that go form the launching of the Alliance for Progress by the Kennedy Administration in 1961, to the 
debt crisis of 1982. This provides a historical background for discussing where is Latin America likely to go in the years to come.

\section{II.1 The Cuban Revolution and the Alliance for Progress}

Starting in the 1940s, most Latin American nations followed an economic strategy based on protectionism, government-led industrialization, and a broad involvement of the state in economic activities. For some time this government-led economic strategy seemed to work: growth picked up in many countries, and industrialization proceeded at a brisk pace. During the 1950s many observers were optimistic and thought that economic development and prosperity were around the corner. But underneath this veneer of success, deep inefficiencies and social tensions were simmering. The newly developed industrial sector was highly inefficient, and in order to survive it required increasingly higher import barriers in the form of tariffs, licenses and quotas. As a result of protectionism the region's currencies became artificially strong, discouraging exports and hurting competitiveness in the agricultural sector. ${ }^{3}$ As the 1950 s unfolded, massive poverty persisted in most nations, and inequality - and, in particular, inequality between the rural and urban sectors - became more pronounced.

In an increasing number of countries the population became frustrated by the lack of progress in social conditions, and by the brutality of authoritarian and dictatorial regimes. The first signs that not everything was well south of the Rio Grande came in 1952 when Guatemalan President Jacobo Arbenz - only the second person elected democratically in that Central American country -- implemented an agrarian reform aimed at redistributing land holdings. His policies were resisted by landowners and large multinationals, and created a serious diplomatic rift with the United States. In 1954 the Guatemalan military staged a coup that put an end to Guatemala’s incipient democracy and Arbenz's socialist program.

The triumph of the Cuban Revolution in 1959 was a major wake-up call for the United States. It quickly became clear that Fidel Castro was serious about creating a Socialist republic 90 miles from the coast of Florida, and that in order to do it he would

\footnotetext{
${ }^{3}$ In his 1971 book (Chapter 5) Corden provides one of the most complete theoretical analyses on the connection between the structure of protection and the equilibrium real exchange rate. His work on the subject was the bases for my own early analysis on Latin America. Indeed my first publication, based on my undergraduate thesis, owes much to Corden’s work on the subject; see Edwards (1975).
} 
rely on Soviet support. But what was even more disturbing to Washington was that Fidel was extremely popular in the rest of Latin America. Guerilla movements tailored after Cuba's $26^{\text {th }}$ of July Movement, quickly sprung in country after country. By 1960, the Cold War had arrived in earnest in Latin America.

The Kennedy Administration decided to tackle this threat through a two-prong strategy: First, military assistance was provided to the region's governments. The aim was to professionalize local armed forces, allowing them to successfully engage Marxist insurgents that had taken to the mountains and jungles. The second component of Kennedy's plan was a vast economic assistance program for the region, named the Alliance for Progress. This was formally launched in August 1961, at the Punta del Este (Uruguay) meeting of the Inter-American Economic and Social Council. Paradoxically, it was at this same meeting that Ernesto Che Guevara announced Cuba’s aggressive policy of nationalizing, without compensation, American investments in the Caribbean island.

The Charter of Punta del Este called for ambitious goals for the Alliance for Progress, including: ${ }^{4}$ (a) achieving a rate of growth of per capita income of at least $2.5 \%$ per annum; (b) a more equitable distribution of income; (c) the diversification of regional exports; (d) the implementation of "programs of comprehensive agrarian reforms"; (e) the elimination of adult illiteracy and the expansion of educational coverage; (f) the construction of massive social housing; (g) low inflation and price stability; and (h) putting in place the polices that would reduce the occurrence of major currency crises. In order to achieve these goals the countries in the region were to develop consistent Economic Plans. The charter also established that the United States, in turn, would provide substantial aid - 2 billion dollars per year --, for at least ten years.

By the late 1960s and early 1970s, a decade after the launching of the Alliance, Latin America was a region of contrasts. In some countries, such as Brazil and Mexico, growth had accelerated significantly, and averaged more than 6\% per year; in others growth was modest at best (Argentina and Chile). In some nations instability and high

\footnotetext{
4 The complete text of "The Charter of Punta del Este" may be found at: http://www.yale.edu/lawweb/avalon/intdip/interam/intam16.htm
} 
inflation was the norm (Argentina), while in others inflation was very low, indeed lower than in the United States (El Salvador, Guatemala, Honduras, Nicaragua).

Most countries, however, shared two characteristics: (a) the degree of openness to international trade (both in goods and financial claims) was low. Indeed, the protectionist policies that had first been implemented in the 1930s in an effort to encourage industrialization - the so called import substitution industrialization (ISI) strategies -, intensified during the 1960s and 1970s. These policies helped create a highly inefficient domestic manufacturing sector, and resulted in an artificial strengthening of local currencies. This, in turn, discouraged exports and reinforced the region's economic quasi-isolation. ${ }^{5}$ Effective rates of protection for manufacturing goods in Latin America were among the highest in the world. At the same time effective protection in agriculture was negative in most of the region. ${ }^{6}$ And (b), in most countries social conditions failed to improve significantly; poverty continued to be widespread, and income distribution remained extremely unequal. Indeed, by the early 1970s many Latin American countries were among those with the most unequal income distribution in the world. ${ }^{7}$

\section{II.2 Oil Shocks and Debt Crisis}

The oil price shocks of 1973 and 1979 shaped in a fundamental way the path followed by the Latin American countries during the last quarter of the 20th century. Oil exporters - and, in particular Mexico and Venezuela - embarked on ambitious development plans aimed at rapid industrialization. Most of this effort was led by the public sector, and consisted of implementing large and, as it turned out, inefficient investment projects. As a way of leveraging the oil monies, governments in the oil exporting countries borrowed heavily from the rest of the world, and rapidly accumulated very large external debts.

Oil importing countries tried to cushion the sudden worsening in their terms of trade - or prices of exports relative to imports -- by borrowing liberally from abroad. As their oil-exporting neighbors, they accumulated foreign debt at a pace that turned out to be unsustainable.

\footnotetext{
5 See Diaz Alejandro (1981).

6 Max Corden pioneered the use of the effective rate of protection (ERP) in analyses of the effects of commercial policy on output, welfare and the economic structure. See, for example, Corden (1966a, 1966b, and 1971). On effective protection in Latin America, see Edwards (1993).

7 See Edwards (1995).
} 
In the aftermath of the first oil shock of 1973, many countries that for decades had maintained macroeconomic stability - mostly the countries of Central America - began to rely on monetary expansion to finance rapidly increasing government expenditures. As a result, inflation increased, exports loss competitiveness, and international reserves declined rapidly. ${ }^{8}$ Most countries responded to this situation by implementing exchange and capital controls. As macroeconomic disequilibria became more acute, a number of governments adopted multiple exchange rate regimes, where different transactions, including exports of different varieties of the same good, were subject to different exchange rates. These systems were highly inefficient and encouraged corruption, and eventually forced many Latin American countries to devalue their currencies and abandon their decades-long fixed exchange rate regimes.

In August of 1982 Mexico stunned the world when it announced that it was unable to meet a payment on its foreign debt. As analysts would later find out, most of the oil money had been squander in highly inefficient investment projects, most of which were affected by graft and corruption. The international financial community was shocked by the news, and rapidly began to retract from the region; country after country experienced what later became to be known as a "sudden stop" of capital inflows. ${ }^{9}$ Although no one knew it then, by the end of 1982 Latin America had entered one of the darkest periods in its history, the so-called “lost decade.” During the next seven years income per capita in most Latin American countries barely grew, social conditions worsened quickly, and some countries suffered serious bouts of hyperinflation. In 1989 the rate of inflation in Argentina exceeded 3,000\%; in Bolivia it was higher than 11,750\% in 1985, and in Brazil it climbed to 3,000\% in $1990 .^{10}$

\section{II.3 Heterodox Plans and Populism during the 1980s}

In the mid 1980s a number of plans were put in place in efforts to find a "silver bullet” that would expeditiously solve the debt crisis and return the region to growth, low inflation and stability. Plans based on heterodox ideas, such as generalized price controls

\footnotetext{
8 The currencies of El Salvador, Guatemala, Honduras, and Nicaragua were for decades pegged to the U.S. dollar. Costa Rica was an exception in Central America, and suffered from periodic currency crises.

${ }^{9}$ See, Calvo (2003)

${ }^{10}$ Max Corden contributed greatly to the analysis of this period of macroeconomic turmoil in Latin America. See, Little, Cooper, Corden and Rajapatirana (1993).
} 
and half-baked monetary reforms, were implemented in Argentina (Austral Plan) Brazil (Cruzado Plan), and in Peru (Plan Inti).

Many countries resorted to pegging the value of the local currency to the U.S. dollar; it was though that by controlling the price of foreign exchange, import prices would stabilize and inflation would decline. These policies appeared to work at first, but it soon became apparent that fixing the exchange rate at an artificial level was not sustainable; exports’ competitiveness declined, imports became very cheap, and large trade deficits developed. In particular, pegging the exchange rate in the face of ongoing fiscal and monetary disequilibria proved to be a recipe for disaster. As a result of these policies, scarce foreign currency reserves plummeted, furthering macroeconomic imbalances.

Many of the heterodox programs of the 1980s were populist, in the sense that they used unsustainable macroeconomic policies to obtain short term benefits - including income distribution effects --, without regard for long term consequences. This was particularly the case in Peru, where under the leadership of President Alan García the fiscal deficit ballooned, and money was printed at increasingly rapid rates by the Central Bank. At the same time, and in an effort to quell inflation, prices were tightly controlled at artificial levels. These populist policies ended up in failure: inflation skyrocketed, unemployment went through the roof, and growth was negative. Worse yet, Peru spiraled into political chaos, with the Maoist Shining Path guerilla movement taking control of vast parts of the countryside. ${ }^{11}$

By the mid and late 1980s inflation was out of control in countries as diverse as Argentina, Bolivia, Brazil, Peru, and Uruguay. As it has always been the case, the poor were the ones that suffered the most. They couldn't protect themselves from the ravaging effects of continuously increasing prices, nor could they move their savings to Miami, Panama City or Zurich.

\section{Market Reforms, Freer Trade and the "Washington Consensus"}

As the years passed, and the region sank further into economic dysfunction, it became increasingly apparent that a solution to the crisis would require coordinated

\footnotetext{
${ }^{11}$ See, Dornbush and Edwards (1991) for a discussion of Peru's experience under President Alan Garcia.
} 
action by the Latin American governments, creditor governments, lenders, and the international multilateral institutions. A breakthrough was achieved in 1989 when the "Brady Plan" was announced. This initiative relied on voluntary debt reduction, and consisted on exchanging old non performing bank debt for new long-term bonds with a lower face value. In order to be eligible to participate in the Brady debt exchanges the Latin American countries had to show a commitment to implement some economic reforms. Mexico and Costa Rica were the first countries to take advantage of this plan in 1989; Venezuela and Uruguay followed in 1990 and 1991, and Argentina and Brazil in $1992 .^{12}$

Agreeing on the details of the Brady Plan was not easy, and took repeated rounds of consultation and bargaining. Negotiations with Mexico - one of the larger debtors became particularly difficult during the first half of 1989. Newly elected president Carlos Salinas de Gortari insisted in obtaining major debt reduction, as well as sizable fresh financial resources. Discussions dragged for months and involved officials from the Federal Reserve Board, as well as from the G-7 governments. In late July 1989, agreement was reached; Mexico received debt relief of approximately 55\% of the face value of its debts.

The implementation of the Brady Plan had two important consequences: First, countries that restructured their debts were able, once again, to access the international financial markets and borrow from abroad. Second, a large secondary market for emerging markets' debt was developed. This market was highly liquid, and allowed all types of investors -- large and small, individual and institutional, long term and speculators -- from all over the world to invest in the developing nations. The fact that this was bonded debt made a significant difference from the pre-1982 situation, when most lending to Latin America (and other emerging countries, for that matter) was in the form of syndicated bank loans.

During the late 1980s and early 1990s an increasing number of Latin American countries embarked on market-oriented reforms. These programs, which have received the name of the "Washington Consensus," were based on efforts to reduce fiscal

\footnotetext{
${ }^{12}$ Max Corden made important contributions to the analysis of alternative ways of dealing with the "debtoverhang" situation created by the crisis. See, for example, Corden (1989a, 1989b), and Corden and Dooley (1989).
} 
imbalances and inflation, open the economy to international trade, deregulate investment and the business sector, develop domestic capital markets, and privatize public enterprises. In addition, there was an effort to reallocate public expenditures towards the poorest segments of society. ${ }^{13}$ These reforms rapidly bore fruit on the macroeconomic front. Inflation declined and with that credit was once again available. In some countries - most notably in Argentina, Chile and Peru - GDP growth increased drastically, exceeding $6 \%$ per annum. ${ }^{14}$

In contrast with the Alliance for Progress, the Washington Consensus was not an officially sanctioned economic program. It was rather a collection of loosely articulated ideas aimed at modernizing, deregulating and reforming the Latin American economies. There has been considerable controversy on whether the name Washington Consensus correctly reflects the origin of these ideas. I have argued elsewhere that the Washington institutions - the U.S. Treasury, the World Bank and the International Monetary Fund had little to do with the launching of these market oriented reforms. Clearly, these reforms were not imposed or forced upon the Latin American governments. They were largely home-grown, and were Latin America's own response to more than a decade of crisis. In fact, the Washington institutions were skeptical - and in some cases openly opposed - to some of the most daring reform proposals. To be sure, as time passed, and more and more countries adopted these policies, Washington began to support the effort. At the end of the road, however, the question is not the genesis of the reform ideas, but why did so many counties - virtually all of the Latin American nations, with the exception of Cuba - embarked on this reform effort. ${ }^{15}$

Trade reform and freer trade were at the heart of the Washington Consensus reforms. It was thought that once the Latin American economies got rid of decades-old protectionist practices, their inefficient local industries would be forced to compete internationally. As a result of competition, productivity would increase, exports would expand, and faster growth would follow in short order.

\footnotetext{
13 See, Williamson (1990).

14 See, Edwards (1995).

15 See Edwards (1995) for a discussion.
} 
In a highly influential article, Williamson (1990) summarized the main goals of the Washington Consensus as follows: ${ }^{16}$

- Achieve fiscal balance, as a way of reducing inflationary pressures.

- Direct public expenditure priorities towards the poor; generalized subsidies, which benefit mostly the middle class, are to be avoided.

- Implement tax reforms that would reduce distortions, lower marginal taxes, and broaden the tax base. Tax administration must improve in order to avoid tax evasion.

- Interest rates ought to be market determined. They should help allocate scarce capital to the most productive uses; they must also be high enough as to discourage capital flight.

- Artificially strong currencies are to be avoided. Exchange rate policies should not discouraged exports, as it had historically been the case in Latin America.

- Wide-ranging trade reforms aimed at integrating the Latin American countries to the global economy should be implemented. Import tariffs and other forms of protectionism should be slashed.

- Foreign direct investment must be encouraged.

- Inefficient state owned enterprises are to be privatized.

- Deregulation ought to be implemented at every level. Red tape should be cut, barriers to entry in key industries must be eliminated, and competition encouraged.

- Legal protection of property rights must be improved.

During the first half of the 1990s country after country began to implement a variety of modernization reforms. Different countries proceeded at different speeds, and emphasized different aspects of the reforms, but the vast majority made progress in four areas: fiscal deficits were reduced; tax reforms were implemented; import quotas were relaxed and import tariffs were lowered; and state owned companies were privatized. In most countries short term results were impressive: inflation declined drastically and

${ }^{16}$ See Williamson (1990). 
growth increased significantly: while in 1989-90 average inflation was 890\%, in 1993-94 it was $124 \%$, GDP growth per capita was 3.5\% in 1993-94, and only $-0.5 \%$ in $1989-90$.

It is not an exaggeration to say that by 1994 there was heightened hope regarding the Latin American nations. All of the sudden it appeared as if, after decades of frustration, the Latin American economies were ready to take off.

But behind these impressive early results hid important weaknesses: Many countries - including the three largest ones, Argentina, Brazil and Mexico - had adopted rigid exchange rate regimes, and had allowed their currencies to strengthen significantly. ${ }^{17}$ This reduced exports' competitiveness in the global market place, and encouraged speculation. ${ }^{18}$ In most countries privatization of public utilities - including energy, water and sanitation, and telecommunications -- was implemented without putting in place proper regulation and competition policies. As a result, state owned monopolies were replaced by privately-owned monopolies. More seriously, perhaps, most reforming nations failed to - or were unwilling to -- move forward in the creation of strong and modern institutions that would encourage the rule of law, protect property rights and reduce the extent of corruption. Although these three areas - competitive exchange rates, competition policies, and institutional reforms --, were part of the original Washington Consensus Decalogue, most countries in the region paid only lip service to them.

\section{Crises and of the Reaction Against the Washington Consensus in the 2000s}

During the second half of the 1990s and early 2000s hope was replaced by a chain of deep and traumatic crises. In December 1994, and after a year of political upheaval that included the Chiapas uprising and the assassination of the ruling party's presidential candidate, the Mexican Peso collapsed and was devalued by more than 65\%. The Mexican crisis generated a wave of “contagion” through the region, testing the strength of the reformed economies. Capital flows into Latin America declined, and the cost of borrowing internationally -- as measured by the spread paid by Latin American bonds

\footnotetext{
${ }^{17}$ Max Corden's Ohlin Lectures dealt with the choice of the exchange rate regime. See Corden (2002).

${ }^{18}$ The strengthening of regional currencies was to a large extent the result of very large capital inflows into the Latin American countries. The effects of these inflows on real exchange rates and resource allocation were similar to those generated in Dutch-Disease cases. See Corden and Neary (1982).
} 
over and above the yield on U.S. Treasuries --, increased significantly. Argentina, a country that had chosen a fixed exchange rate regime and a currency board, was particularly affected by what came to be known as the "tequila effect."

In mid 1997, when the region was beginning to recover from the Mexican currency collapse of 1994, the world was shocked by the eruption of severe crises throughout South East Asia. Thailand was the first to go, followed by Indonesia, the Philippines, Malaysia, and South Korea. Although Latin America had limited trade and financial exposure to South East Asia, it was still subject to contagion. In mid 1998 the global financial system was affected by two new crises and new bouts of contagion. In August the Russian ruble was devalued, and in September the failure of the investment firm Long Term Capital Management, exposed the fragilities of a system, where it was possible, through the use of derivatives, to take huge open positions in international financial markets. Following these crises, capital flows to the emerging countries declined significantly, forcing many Latin American nations to implement severe current account adjustments.

During the next few years a succession of severe balance of payment crises that resulted in the collapse of currency values and large increases in unemployment erupted in a number of Latin American countries: Brazil in 1999, Argentina in 2001, Uruguay in 2002, and the Dominican Republic in 2003. Growth declined throughout the region, unemployment increased rapidly, and social conditions deteriorated. Between 1998 and 2004 the average rate of per capita growth in Latin America was a disappointing 0.75\%

The Argentine devaluation crisis of 2001 was particularly painful. In December of that year, and after a week of riots and political unrest, Fernando de la Rua, Argentina's constitutionally elected President, resigned. A few weeks later Argentina defaulted on its foreign currency debt, and went through one of the most traumatic devaluation crises in modern history. In little over two months the peso, which for more than a decade had been pegged to the U.S. dollar at a one-to-one rate, lost two thirds of its value. The depth of the crisis was such that in a period of a few weeks the country went through 5 presidents. In many ways, Argentina epitomizes Latin America's 
historical proclivity towards macroeconomic instability, trade imbalances and runaway inflation. ${ }^{19}$

An increasing number of analysts began to criticize the Washington Consensus and the market oriented reforms during the first half of the 2000s. Three interrelated policy issues were at the center of these criticisms: (1) in designing reform packages during the 1990s, crucial aspects of the sequencing and pace of reform were ignored. As a result, it was argued, in many countries reforms were implemented too fast and in the wrong order. (2) Advocating (and imposing) capital account liberalization was a serious mistake; it encouraged short term capital flows, fueled speculation, and increased the countries vulnerability to crises. And (3), the IMF involvement in the Argentinean saga, and eventual crisis, was a disaster that made things worse rather than better. ${ }^{20}$

Critics of the Consensus also argued that the initial reform blueprint ignored the need to reform institutions. This, however, was largely an unfounded criticism. Indeed, the Washington Consensus Decalogue presented above makes clear that there was a need to improve institutions - including institutions that protect property rights and competition. At the design level, however, most countries decided to proceed following a specific sequence: the initial steps would reform the economy's structure and incentives; only when these reforms were consolidated would institutions be strengthened and new institutions created. Of course, by choosing this specific sequencing, policy makers and their advisors were implicitly saying that institutions were not as important as economic policies or, at least, that they were not as important during the transition period.

As a result of the macroeconomic crises and economic setbacks of the late 1990s and early 2000s, frustration erupted across most of Latin America, and the public grew increasingly skeptical about the merits of globalization and market orientation. In election after election voters turned to the left, and elected Presidents that were clearly critical of the Washington Consensus. Some of these new leaders - Hugo Chávez of Venezuela and Evo Morales of Bolivia - have been very vocal in their criticisms; others, have been more subdued. Most of them, however, have argued that the region needs to increase spending in social programs as a way of reducing inequality. In some countries -

${ }^{19}$ For a narrative of the Argentine crisis see Blustein (2005).

${ }^{20}$ See Stiglitz (2002) and Rodrik (2003). 
- Bolivia, Ecuador and Venezuela - the new political leaders have announced policies that would undo some of the reforms of the 1990s. ${ }^{21}$ These policies included the nationalization of industries, increased government controls, and higher import tariffs.

In 2003-2007, and largely as a result of improving commodity prices and favorable global financial conditions, the Latin American countries experienced a surge in growth -- real per capita GDP growth averaged 3.2\%. The recovery was particularly pronounced in countries recovering from deep crises, such as Argentina and Venezuela. In addition to the pickup in growth, other macroeconomic indicators also improved during this period: in most countries external debt has declined and inflation has stayed in check. The combination of economic recovery and political movement to the left has raised questions about the economic future of Latin America. In particular, will higher growth be sustained? Will social conditions improve? Will the region be able to avoid crises and currency collapses? In short, and using a term coined by Albert Hirschman four decades ago, Is there a bias for hope? ${ }^{22}$ Or will the region, once again, adopt populist policies that emphasize short term gains at the cost of longer term sustainability?

\section{The Cost of External Crises in Latin America: An Empirical Analysis}

An important question, within the context of Latin America's economic history, is How costly have external crises been? In this Section I address this issue by estimating a number of variance component models of the dynamics of growth. More specifically I estimate by how much growth (and the level of real GDP) have been reduced, on average, as a consequence of two type of external crisis: sudden stops of capital inflows, and current account reversals. ${ }^{23}$ The analysis presented in this Section expands previous work on the subject in two important respects: First, I explore several equation specifications that allow for very flexible dynamic responses of both growth and real GDP to external disturbances. Second, I use a set of new instruments to deal with

\footnotetext{
${ }^{21}$ Of course, not all elected leaders in the mid 2000s were globalization critics; Felipe Calderón of Mexico and Alvaro Uribe of Colombia are examples of presidents that support market orientation.

${ }^{22}$ See, Hirschman (1968). In a recent book Santiso (2006) also asks Hirschman’s "hope” question.

${ }^{23}$ Max Corden addressed the costs of crises in his 1993 book - coauthored with Ian M.D. Little, Richard N. Cooper and Sarath Rajapatirana -- on crisis and adjustment in developing nations. He also dealt with this question in Chapter 8 on contractionary devaluations in his Ohlin Lecture volume (Corden, 2002).
} 
possible endogeneity issues arising in the estimation of the growth dynamic equations. The data set covers the years 1970-2004.

\section{V.1 The Model}

The analysis is based on a two-equation representation of the dynamics of real GDP per capita growth of country $j$ in period $t$. Equation (1) captures long run GDP growth in a way consistent with the "new growth" empirical literature; equation (2) captures the growth dynamics process. ${ }^{24}$

$$
\begin{aligned}
& g_{j}^{*}=\alpha x_{j}+\theta z_{j}+\gamma s_{j}+\varepsilon_{j} \\
& \Delta g_{j t}=\lambda\left(g_{j}^{*}-g_{j t-1}\right)+\beta \Delta g_{j t-1}+\varphi v_{j t}+\gamma u_{j t}+\xi_{j t} .
\end{aligned}
$$

In equation (1) long term per capita GDP growth in country $\mathrm{j}\left(g_{j}^{*}\right)$ is related to structural variables $\left(x_{j}\right)$, policy variables $\left(z_{j}\right)$, and institutional variables $\left(s_{j}\right)$. The error term $\left(\varepsilon_{j}\right)$ is assumed to be heteroskedastic. In equation (2), $g_{j t}$ is the rate of growth of per capita GDP in country $j$ in period $t$. The terms $v_{j t}$ and $u_{j t}$ are shocks, assumed to be zero mean, finite variance and to be uncorrelated among them. More specifically, $v_{j t}$ is assumed to be an external terms of trade shock, while $u_{j t}$ captures other shocks, including sudden stops and current account reversals. $\xi_{\mathrm{tj}}$ is an error term, which is also assumed to be heteroskedastic. $\lambda, \beta, \varphi$, and $\gamma$ are parameters that determine the particular characteristics of the growth process. Equation (2) -- which has the form of an equilibrium correction model --, states that the actual rate of growth in period $t$ will deviate from the long run rate of growth due to the existence of four types of shocks, including deviations of (the lagged value of) actual growth and trend growth $\lambda\left(g_{j}^{*}-g_{j t-1}\right)$, and a lagged growth acceleration term $\beta \Delta g_{j t-1}$. In this formulation it is expected that $0<\lambda<1$, and $\beta \leq 0$.

24 This formulation is an extension of that of Edwards and Levy Yeyati (2005) and Edwards (2007a). 
According to equation (2), over time the actual rate of growth will tend to converge towards it long run value. The specific way in which convergence will take place is an empirical issue, and depends on the estimated values of parameters $\lambda$ and $\beta$. For instance, if $\beta=0$, and $0<\lambda<1$, equation (2) will be a simple partial adjustment model, where after a shock the actual rate of growth of will return to its long trend value slowly, without ever crossing that long term growth value. If, however, $\beta<0$, it is possible for the actual rate of growth to overshoot/undershoot its long term value $g_{j}^{*}$. For this to be the case it is required that $\lambda<|\beta|$. As pointed out above, whether this will be the case is an empirical issue.

Perhaps the simplest way of empirically addressing this model is by estimating a simple panel regression of per capita growth with country specific dummies for the intercept. In this case the regressors would be once and twice lagged growth, as well as the different shocks. Each country specific dummy is an estimate of $\lambda g_{j}^{*}$ for that particular country. From the coefficients of $g_{t-1}$ and $g_{t-2}$ it is possible to find the estimated value of $\lambda$, and from the country specific intercepts the estimated long term trend rate of growth for each country. An alternative strategy, and the one followed in this paper, is to use a two stages procedure. In the first stage long term cross country averages are used to estimate the long term growth equation (1). The first stage results are then used to generate long-run predicted growth rates for each country; these are used in the estimation of the growth dynamic equation (2) in the second stage. The main advantage of this approach is that long term growth is, in fact, related to those variables policy, structural, and institutional -- that according to modern economic analysis affect economic performance in the long run.

The main interest from the perspective of the discussion in this paper is the effect of sudden stops and current account reversals on growth; that is, whether coefficient $\gamma$ is significantly negative. A sudden stop is defined as a reduction in net capital inflows of at least 5\% of GDP in one year. ${ }^{25}$ A current account reversal, on the other hand, is defined

\footnotetext{
${ }^{25}$ To qualify as a sudden stop episode, the country in question must have been a net importer of capital in the previous year. In order to check for the robustness of the results, I also used two alternative definitions of sudden stops, which considered a reduction in inflows of 3 and $7 \%$ of GDP in one year.
} 
as a reduction in the current account deficit of at least 4\% of GDP in one year. ${ }^{26}$ In the estimation of equation (2), I used dummy variables for sudden stops and reversals. See the Data Appendix for details. The results obtained in the first stage on long term growth are not reported due to space considerations ${ }^{27}$. It should be noted, however, that they generally support the notion that long term economic performance depends on structural variables, policy variables - in particular, policies that encourage competition --, and variables that measure the strength of economic, judicial, and political institutions.

\section{V.2 Basic Results}

In this Subsection I present the results obtained from the estimation of the growth dynamic equation (2). One of the difficulties in this analysis is the potential endogeneity of the current account reversal and sudden stop variables. In order to deal with this issue I also present the results from instrumental variables estimation of equation (2) using the procedure suggested by Maddala (1983) and Keshk (2003) for systems where one of the endogenous variables is dichotomous. ${ }^{28}$

In Table 1 I present the results from the estimation of the growth dynamics equation (2) using a variance component random effects GLS procedure; robust standard errors are reported. Table 2, on the other hand, contains the estimates obtained using Maddala’s (1983) instrumental variables approach; again, robust standard errors are provided. The following instruments were used: change in the international terms of trade (current and lagged one period); the proportion of countries in each region (excluding the country in question) subject to a sudden and large decline of net capital inflows, lagged one period; world real interest rates lagged one and two periods; a dummy variable that takes the value of one if the country in question has suffered a major storm (tornado, hurricane and others); and a two-period lagged dummy that takes the value of one if there was a war in the country's territory, the proportion of countries in each region (excluding the country in question) subject to a war in that period. In each table the first two columns refer to the complete sample, while the second two are for the Latin American countries only.

\footnotetext{
${ }^{26}$ I also used an alternative definition. The qualitative nature of the results discussed below, were not affected by the precise definition of reversals or sudden stops. See Edwards (2007a).

${ }^{27}$ See Edwards (2007a) for a detailed analysis of the long run growth in Latin America.

${ }^{28}$ See also Heckman (1978) and Amemiya (1978).
} 
These results show that external crises have been very costly for Latin America. In all regressions the crises coefficients are significantly negative. Moreover, these regressions suggest that crises have been significantly more costly in Latin America than in the rest of the world. The estimated coefficients of the current account reversal variable ranges from -3.6 to -3.7 for Latin America; for the complete sample it goes from -1.3 to -2.1 . The estimated coefficients for the sudden stop variable ranges from -2.6 to -2.8; it ranges from -0.9 to -2.0 for the complete sample. Not surprisingly, this suggests that current account reversals imply a greater cost - in terms of lower growth - than sudden stops. Indeed, when both variables are included in the same regression the coefficient of sudden stops becomes insignificant.

These results also show that terms of trade shocks have had significant effects on growth. Improvements in terms of trade accelerate growth, while lower terms of trade result in growth slowdowns. The terms of trade coefficients range from 0.80 and 0.11 , and through some light on the question of the future of Latin America. They indicate that a decline of the region's terms of trade towards “normal” long term levels is likely to have a significant effect on growth; at the same time, these estimates suggest that the acceleration in the rate of growth in Latin America after 2002 is largely the result of improved international terms of trade. I return to these issues in the concluding Section of the paper.

The estimates of coefficients $\lambda$ and $\beta$ reported in Tables 1 and 2 indicate that the dynamics of growth is different in Latin America that in the rest of the world; for both samples, however, it is rather simple, as there is no evidence of overshooting. In Table 1 on GLS estimates the coefficients of $\beta$ are significantly positive for the Latin American regressions; for the complete sample, it is insignificant in column 1, and marginally negative in column 2. The results in Table 2 on $\lambda$ and $\beta$ are somewhat different, but it is still the case that $\lambda>|\beta|$; this means that once affected by a shock the rate of growth will converge smoothly to its long run value. 


\section{V.3 The Role of Openness}

As pointed out in Section IV, one of the key criticisms of the Washington Consensus is that the emerging countries opened up excessively to the rest of the world. A problem with this line of argument, however, is that there is ample empirical evidence that supports the view that countries that are more open to international trade do better in terms of long term growth, on average, that those with a close economy; the evidence on the effects of financial openness on growth is, on the other hand, inconclusive. ${ }^{29}$

This evidence, however, deals with long term growth and doesn’t say anything regarding the dynamics of growth. It is perfectly possible, for example, that openness both trade and financial - affects the way in which external crisis affect short term growth. I investigated this issue by estimating an expanded version of equation (2), where in addition to the original regressors I included terms that interact the crisis variables and two measures of openness: trade openness, defined as the ratio of imports plus exports over GDP, and financial openness, defined as a 1 to 100 index, with higher values meaning a higher degree of openness (see Data Appendix for details).

The results obtained when the random effects variance component GLS procedure was used are reported in Table 3 (robust standard error in parentheses). As may be seen, the crises variables continue to be significantly negative; the coefficients of the variables that interact trade openness and crisis are, in all regressions, significantly positive; the variables that interact crisis and financial openness are not significantly different from zero. These results indicate that countries that are more open to international trade are less affected by external crises than countries that are more closed to trade. Consider the results in column 1 in Table 3: the impact effect of a current account reversal on per capita growth is:

$$
\text { Impact effect }=-5.99+0.031 \text { Trade Openness. }
$$

That is, if country's degree of trade openness is 20\% of GDP, the growth effect of a reversal is $-5.37 \%$; in contrast, in a very open country with a trade to GDP ratio of $80 \%$ the estimated point effect of a current account reversal on growth is only $-3.51 \%$. These

\footnotetext{
${ }^{29}$ See, for example, Frankel and Roemer (1999), and Eichengreen (2001).
} 
findings suggest, then, that contrary to the recent criticism on globalization and marketoriented reforms, a greater degree of openness reduces the impact of crises on growth. Also, these regressions indicate that financial openness has played no role in determining the effects of crises on performance. A related question, and one that is beyond the scope of this paper, is whether a higher degree of openness affects the probability of suffering a crises. Recent results reported in Edwards (2007a) indicate that a greater degree of financial openness has a significantly positive, but quantitatively very small effect on the probability on experiencing a sudden stop.

\section{Concluding Remarks on Globalization and the Future of Latin America}

In the first four Sections of this paper I discussed the economic history of Latin America, and I analyzed the region's evolution from protectionism and import substitution industrialization in the 1940s, to the market oriented reforms of the 1990s and early 2000s. I pointed out that in the last few years there has been a growing antiglobalization and anti market-oriented reforms in the region. This has been reflected in the election, in country after country, of Presidents that have criticized, to different degrees, the Washington Consensus. This growing skepticism on the merits of market orientation has been translated into different policies in different countries: in some Venezuela, Bolivia, Ecuador, and Nicaragua - it has resulted in the backtracking of the reforms, the imposition of controls, the hiking of import tariffs and the nationalization of some industries. In other - in fact, in the vast majority of countries in the region - this skepticism has resulted in the stalling of the reform effort. Indeed, in most Latin American countries there has been very little progress in the reform front in the last 5 to 7 years. This is true with regard to both competition policies and institutional strengthening and reforms.

In Section IV I argued that the anti reform sentiment was mostly the result of the public's disappointment with the reforms. This disappointment, in turn, was largely the consequence of the deep and very costly macroeconomic and currency crises that affected a large number of countries in the 1990s and 2000s. These crises - Mexico in 1994-95, Brazil in 1999, Ecuador in 1999, Argentina in 2001, Uruguay in 2002, Brazil (again) in 2002, and the Dominican Republic in 2002, to mention only the better known ones - 
resulted in large increases in unemployment, reduced incomes, negative growth, and, in many countries, in an increase in poverty and inequality. What made things worse was that the supporters of the reforms had oversold them, and had implied that the adoption of market orientation and the opening up of the Latin American economies would result in the end of the region's legendary macroeconomic instability. Contagion stemming from crises in other parts of the world - East Asia in 1997-98 and Russia in 1998 - also contributed to the sense of disappointment with globalization. From a political economy perspective, these macroeconomic crises also gave an opportunity to those groups negatively affected by the reforms - including domestic producers threatened by the opening of trade -- to regroup, and mount a more organized opposition to modernization.

In Section V I tackled the question of the costs of crises in a formal way, and I report new results from the estimation of a number of panel regressions on the dynamic of growth, using both random effects GLS and instrumental variables techniques. The analysis focused on two definitions of crises: abrupt and large current account reversals, and large and sudden declines in (net) capital inflows. The most important conclusions of this analysis may be summarized as follows: (1) external crises have been very costly in Latin America; indeed, more costly than in other regions; (2) Current account reversals have been significantly more costly than sudden stops; (3) Improvements (deterioration) in the international terms of trade have a significant effect on short term growth; a $10 \%$ change in the terms of trade results in almost a 1 percentage point change in per capita growth; (4) Latin America has exhibited a simple dynamics of growth during the last few years; that is, the functional form for the dynamics of growth implies smooth adjustments, and rules out overshooting in the short run; (5) countries more open to international trade have suffered a smaller effect of external crises than countries which are relatively closed to international trade. And (6) the degree of financial openness does not appear to affect the intensity with which crises affect growth.

An important question is what to expect of Latin America and its relationship with globalization in the future. Given the region's history, it is unlikely that in the next few years -5 to 10 years, say - there will be a new pro-globalization and pro-reform 
movement. ${ }^{30}$ In that sense, it is important to realize that, as was documented in Section III of this paper, the massive and generalized move towards reforms of the 1990s was largely the result of the deep crisis of the 1980s, and of the dark mood that took over the public in most countries during the years of the so-called "lost decade." The most likely scenario is that in most Latin American countries the public will continue to regard market orientation with great suspicion. As a consequence, the region will be one of incomplete or fractured reforms. And without moving forward in the key areas of competition policies and institutional reforms it is highly unlikely that the region's countries will experience an increase in their long term rate of growth. In that regard, it is likely that, once the terms of trade return to their more normal level, growth will revert to its mediocre long term historical average of approximately $1 \%$ per year in per capita terms. Moreover, it is likely that some countries will revert to economic policies that emphasize government control and increased protectionism. As the region's history discussed in Sections II through IV of this paper has shown, these policies rarely work; in fact, more often than not they result in lower rates of growth over the longer run.

On the positive side, there are some - but only some - indications that the region will experience a decline in the number of currency crises. This is because most countries have implemented, during the last few years, macroeconomic policies that, according to recent research on the subject, reduce the probability of external crises. Most specifically, most countries have reduced their fiscal deficits and public debt; also, they have pared down their foreign debts; the majority of countries are running current account surpluses; and the majority of countries have adopted flexible exchange rates. However, whether these healthy macroeconomic policies will be maintained once terms of trade and the international environment become less friendly, remains an open question.

\footnotetext{
${ }^{30}$ The discussion that follows deals with Latin America's general economic trends; in reality, however, each country has its own reality and its own history. Going into a detailed country-by-country analysis is beyond the scope of this paper, however.
} 


\section{References}

Amemiya, T., 1978. The Estimation of a Simultaneous Equation Generalized Probit Model. Econometrica 46 (5), pp. 1193-1205.

Blustein, P., 2005 And the Money Kept Rolling in (and out). New York: Public Affairs. Calvo, G., 2003. Explaining Sudden Stops, Growth Collapse and BOP Crises: The case of distortionary output taxes. IMF Mundell-Fleming Lecture, IMF Staff Papers 50 (Special Issue), pp. 1-20.

Corden, M. and Dooley, P. D., 1989. Issues in Debt Strategy; an Overview. In J.A. Frenkel et al., (eds.), Analytical Issues in Debt. Washington: International Monetary Fund.

Corden, M., 1966a. The Structure of a Tariff System and the Effective Protective Rate. Journal of Political Economy 74 (3), pp. 221-37.

Corden, M., 1966b. The Effective Protective Rate, the Uniform Tariff Equivalent and the Average Tariff. The Economic Record 42(98), pp. 200-16.

Corden, M., 1971. The Theory of Protection. Oxford: Clarendon Press

Corden, M., 1989a. An International Debt Facility?. In J.A. Frenkel, et al., (eds.), Analytical Issues in Debt. Washington, D.C.: International Monetary Fund.

Corden, M., 1989b. Debt Relief and Adjustment Incentives. In J.A. Frenkel et al., (eds.), Analytical Issues in Debt. Washington, D.C.: International Monetary Fund.

Corden, M., 2002. Too Sensational: On the Choice of Exchange Rate Regimes. Cambridge: MIT Press.

Corden, M., and Neary, J. P., 1982. Booming Sector and De-industrialization in a Small Open Economy, The Economic Journal 92(368), pp. 1-24.

Díaz - Alejandro, C. F., 1983. Stories of the 1930s for the 1980s. In P. Aspe Armella, R. Dornbusch and M. Obstfeld.(eds.) Financial Policies and the World Capital 
Market: The Problem of Latin American Countries, Chicago: University of Chicago Press.

Dornbush, R. and Edwards, S., 1991. The Macroeconomics of Populism in Latin America. Chicago: University of Chicago Press.

Edwards, S., 1975. Shadow Price of Foreign Exchange and Effective Protection. Cuadernos de Economía 12, pp. 127-144.

Edwards, S., 1993. Latin American Economic Integration: A New Perspective on an Old Dream. The World Economy 16 (3), pp. 317-338.

Edwards, S., 1995. Crisis and Reform in Latin America: From Despair to Hope. Oxford University Press.

Edwards, S., 2007a. Crises and Growth: A Latin America Perspective. Journal of Iberian and Latin American Economic History, Forthcoming.

Edwards, S., 2007b. The Decline of Latin America, The University of Chicago Press.

Edwards, S., 2007c. Capital controls, capital flow contractions, and macroeconomic vulnerability. Journal of International Money and Finance 26 (5), pp. 814-840.

Edwards, S. and Levy-Yeyati, E., 2005. Flexible exchange rates as shock absorbers. European Economic Review 49 (8), pp. 2079-2105.

Eichengreen, B. J., 2001. Capital Account liberalization: What do Cross Country Studies Tell us?. The World Bank Economic Review 15 (3), pp. 341-365.

Frankel, J. A. and Romer, D., 1999. Does Trade Cause Growth?, American Economic Review 89 (3), pp. 379-399.

Heckman, J., 1978. Dummy Endogenous Variables in a Simultaneous Equation System. Econometrica 46, pp. 931-960.

Hirschman, A., 1968. The Political Economy of Import-Substituting Industrialization in Latin America. Quarterly. Journal of Economics. 82 (1), pp. 1-32.

Keshk, O. M. G., 2003. CDSIMEQ: A Program to Implement Two-Stage Probit Least Squares. Stata Journal 3 (2), pp. 157-167. 
Little, I., Cooper, R., Corden, M. and Rajapatirana S., 1993. Boom, Crisis and Adjustment: The Macroeconomic Experience of Developing Countries New York: Oxford University Press, for the World Bank.

Maddala, G. S., 1983. Limited-Dependent and Qualitative Variables in Econometrics. Cambridge : Cambridge University Press.

Mody, A., Murshid, A. P., 2002. Growing Up with Capital Flows. Journal of International Economics 65 (1), 249-66.

Prados de la Escosura, L. When did Latin America Fall Behind? In Edwards, S. (Ed.), The Decline of Latin America, The University of Chicago Press.

Quinn, D. P., 2003. Capital Account Liberalization and Financial Globalization, 18901999: a Synoptic View. International Journal of Finance and Economics 8 (3), pp. 189-204.

Rodrik, D., 2006. "Goodbye Washington Consensus, Hello Washington Confusion? A Review of the World Bank's 'Economic Growth in the 1990s: Learning from a Decade of Reform’". Journal of Economic Literature 44 (4), pp. 973-987.

Santiso, J. 2006. Latin America’s political economy of the possible: beyond good revolutionaries and free-marketeers. Cambridge: MIT Press.

Stiglitz, J. E., 2002. Globalization and Its Discontents. New York : W. W. Norton

Williamson, J. 1990. Latin American Adjustment: How Much has Happened?, Institute of International Economics.

World Bank, 2003. Inequality in Latin America and the Caribbean: Breaking with History? The World Bank. 


\section{Data Appendix}

\begin{tabular}{|c|c|c|}
\hline Variable & Definition & Source \\
\hline Change in Terms of Trade & $\begin{array}{l}\text { Change in term of trade export as } \\
\text { capacity to imports (constant } \\
\text { local currency unit) }\end{array}$ & World Development Indicators \\
\hline Current Account Reversal & $\begin{array}{l}\text { Reduction in the current account } \\
\text { deficit of at least } 4 \% \text { of GDP in } \\
\text { one year. }\end{array}$ & $\begin{array}{l}\text { Author's elaboration based on } \\
\text { data of current account (World } \\
\text { Development Indicators) }\end{array}$ \\
\hline Financial openness & $\begin{array}{l}1 \text { to } 100 \text { index, with higher values } \\
\text { meaning a higher degree of } \\
\text { openness }\end{array}$ & $\begin{array}{l}\text { Author's construction based on } \\
\text { indexes of capital restrictions } \\
\text { computed by Quinn (2003) and } \\
\text { Mody and Murshid (2002), and } \\
\text { on country specific data. See } \\
\text { Edwards (2007c) for details }\end{array}$ \\
\hline GDP per capita growth & $\begin{array}{l}\text { Annual \% change in real per } \\
\text { capita GDP. . }\end{array}$ & World Development Indicators \\
\hline Inflation & $\begin{array}{l}\text { Annual \% change in consumer } \\
\text { prices index. }\end{array}$ & World Development Indicators \\
\hline Major Storm & $\begin{array}{l}\text { Dummy }=1 \text { if there was a storm. } \\
0 \text { otherwise }\end{array}$ & $\begin{array}{l}\text { EM-DAT: The OFDA/CRED } \\
\text { International Disaster Database }\end{array}$ \\
\hline Sudden Stop & $\begin{array}{l}\text { Episodes where (1) the country in } \\
\text { question received an inflow of } \\
\text { capital (relative to GDP) larger } \\
\text { than its region's third quartile } \\
\text { during the two years prior to the } \\
\text { "sudden stop.”, and (2) net capital } \\
\text { inflows declined by at least 5\% of } \\
\text { GDP in one year. }\end{array}$ & $\begin{array}{l}\text { Author's elaboration based on } \\
\text { data of capital flows (World } \\
\text { Development Indicators) }\end{array}$ \\
\hline Sudden Stops in Region & $\begin{array}{l}\text { Relative occurrence of sudden } \\
\text { stops in the country's region } \\
\text { (excluding the country itself) }\end{array}$ & Author's elaboration. \\
\hline Trade Openness & $\begin{array}{l}\text { Ratio of imports plus exports } \\
\text { over GDP }\end{array}$ & $\begin{array}{l}\text { Author's elaboration based on } \\
\text { data of international trade (World } \\
\text { Development Indicators) }\end{array}$ \\
\hline War & $\begin{array}{l}\text { Dummy = } 1 \text { if there was a } \\
\text { conflict in country's territory. } 0 \\
\text { otherwise }\end{array}$ & $\begin{array}{l}\text { UCDP/PRIO Armed Conflicts } \\
\text { Dataset }\end{array}$ \\
\hline World Interest Rate & U.S. Real Interest Rate & International Monetary Fund \\
\hline
\end{tabular}




\section{Table 1}

The Dynamics of Growth and Crises, 1970-2004:

\section{GLS, Random Effects Estimates}

\begin{tabular}{|c|c|c|c|c|}
\hline & Eq 1.1 & Eq 1.2 & Eq 1.3 & Eq 1.4 \\
\hline Growth Gap & $\begin{array}{c}0.76 \\
(23.06) * * *\end{array}$ & $\begin{array}{c}0.71 \\
(21.42) * * *\end{array}$ & $\begin{array}{c}0.75 \\
(12.57) * * *\end{array}$ & $\begin{array}{c}0.72 \\
(11.77) * * *\end{array}$ \\
\hline Change in Terms of Trade & $\begin{array}{c}0.09 \\
(11.23) * * *\end{array}$ & $\begin{array}{c}0.08 \\
(10.86) * * *\end{array}$ & $\begin{array}{c}0.09 \\
(6.52) * * *\end{array}$ & $\begin{array}{c}0.08 \\
(5.09) * * *\end{array}$ \\
\hline Growth Lag & $\begin{array}{l}-0.02 \\
(0.82)\end{array}$ & $\begin{array}{c}-0.04 \\
(1.71) *\end{array}$ & $\begin{array}{c}0.12 \\
(2.59) * * *\end{array}$ & $\begin{array}{c}0.11 \\
(2.33) * *\end{array}$ \\
\hline Reversal & $\begin{array}{c}-2.07 \\
(5.64) * * *\end{array}$ & -- & $\begin{array}{c}-3.58 \\
(5.88) * * *\end{array}$ & -- \\
\hline Sudden Stop & -- & $\begin{array}{c}-0.86 \\
(1.7) *\end{array}$ & -- & $\begin{array}{c}-2.59 \\
(2.53) * *\end{array}$ \\
\hline \multicolumn{5}{|l|}{ R-squared } \\
\hline within & 0.472 & 0.459 & 0.443 & 0.403 \\
\hline between & 0.518 & 0.020 & 0.018 & 0.015 \\
\hline overall & 0.445 & 0.431 & 0.430 & 0.387 \\
\hline Number of observation & 2332 & 2234 & 557 & 548 \\
\hline Number of groups & 94 & 93 & 20 & 20 \\
\hline
\end{tabular}

Absolute values of robust z-statistics are reported in parentheses. *** significant at $1 \%$; $* *$ significant at $5 \%$; significant at $10 \%$. 
Table 2

The Dynamics of Growth, 1970-2004:

Two-Steps Maddala Procedure

$\begin{array}{llll}\text { Eq 2.1 } & \text { Eq 2.2 } & \text { Eq } 2.3 & \text { Eq } 2.4\end{array}$

\begin{tabular}{lcccc} 
Growth Gap & 0.72 & 0.68 & 0.88 & 0.63 \\
& $(28.22)^{* * *}$ & $(19.12)^{* * *}$ & $(9.91)^{* * *}$ & $(6.64)^{* * *}$ \\
Change in Terms of Trade & 0.10 & 0.09 & 0.16 & 0.06 \\
& $(12.94)^{* * *}$ & $(10.09)^{* * *}$ & $(5.09)^{* * *}$ & $(2.58)^{* * *}$ \\
Growth Lag & -0.06 & -0.10 & 0.11 & -0.05 \\
& $(2.85)^{* * *}$ & $(3.00)^{* * *}$ & $(1.67)^{*}$ & -0.45 \\
Reversal & -1.25 & & -3.72 & \\
& $(4.22)^{* * *}$ & & $(3.06)^{* * *}$ & \\
Sudden Stop & & -2.08 & & -2.86 \\
& & $(3.1)^{* * *}$ & & $(2.73) * * *$ \\
\hline & & & & \\
R-squared & 0.436 & 0.437 & 0.419 & 0.421 \\
R-squared adjusted & 0.433 & 0.434 & 0.407 & 0.408 \\
\hline & & & & \\
Number of observation & 2166 & 2157 & 530 & 529 \\
\hline
\end{tabular}

Absolute values of corrected $\mathrm{t}$ statistics are reported in parentheses. For list of instruments, see the text. *** significant at $1 \%$; ** significant at 5\%; * significant at $10 \%$.. Both R-squared and R-squared adjusted from the first stage. 
Table 3

The Dynamics of Growth, Crises and Openness, 1970-2004:

\section{GLS, Random Effects Estimates}

\begin{tabular}{|c|c|c|c|c|c|c|}
\hline & Eq 3.1 & Eq 3.2 & Eq 3.3 & Eq 3.4 & Eq 3.5 & Eq 3.6 \\
\hline Growth Gap & $\begin{array}{c}0.77 \\
(12.98) * * *\end{array}$ & $\begin{array}{c}0.75 \\
(12.53) * * *\end{array}$ & $\begin{array}{c}0.77 \\
(12.94) * * *\end{array}$ & $\begin{array}{c}0.73 \\
(11.81)^{* * *}\end{array}$ & $\begin{array}{c}0.72 \\
(11.75)^{* * *}\end{array}$ & $\begin{array}{c}0.73 \\
(11.80) * * *\end{array}$ \\
\hline Change in Terms of Trade & $\begin{array}{c}0.1 \\
(6.70)^{* * *}\end{array}$ & $\begin{array}{c}0.1 \\
(6.52)^{* * *}\end{array}$ & $\begin{array}{c}0.1 \\
(6.68) * * *\end{array}$ & $\begin{array}{c}0.08 \\
(5.07) * * *\end{array}$ & $\begin{array}{c}0.08 \\
(5.07) * * *\end{array}$ & $\begin{array}{c}0.08 \\
(5.06) * * *\end{array}$ \\
\hline Growth Lag & $\begin{array}{c}0.11 \\
(2.57)^{* * *}\end{array}$ & $\begin{array}{c}0.12 \\
(2.61)^{* * *}\end{array}$ & $\begin{array}{c}0.11 \\
(2.57) * * *\end{array}$ & $\begin{array}{c}0.12 \\
(2.36) * * *\end{array}$ & $\begin{array}{c}0.11 \\
(2.33) * * *\end{array}$ & $\begin{array}{c}0.11 \\
(2.35) * * *\end{array}$ \\
\hline Reversal & $\begin{array}{c}-5.99 \\
(6.28) * * *\end{array}$ & $\begin{array}{c}-4.61 \\
(2.67) * * *\end{array}$ & $\begin{array}{c}-6.05 \\
(3.66) * * *\end{array}$ & -- & -- & -- \\
\hline Reversal*Trade Openness & $\begin{array}{c}0.03 \\
(3.77)^{* * *}\end{array}$ & -- & $\begin{array}{c}0.03 \\
(3.17)^{* * *}\end{array}$ & -- & -- & -- \\
\hline Reversal*Financial Openness & -- & $\begin{array}{c}0.02 \\
(0.73)\end{array}$ & $\begin{array}{l}0.001 \\
(0.05)\end{array}$ & -- & -- & -- \\
\hline Sudden Stop & -- & -- & -- & $\begin{array}{c}-4.48 \\
(2.64) * * *\end{array}$ & $\begin{array}{c}-4.18 \\
(1.64) *\end{array}$ & $\begin{array}{c}-5.07 \\
(1.93) *\end{array}$ \\
\hline Sudden Stop*Trade Openness & -- & -- & -- & $\begin{array}{c}0.03 \\
(1.88) *\end{array}$ & -- & $\begin{array}{l}0.02 \\
(1.6)\end{array}$ \\
\hline Sudden Stop*Financial Openness & -- & -- & -- & -- & $\begin{array}{c}0.03 \\
(0.81)\end{array}$ & $\begin{array}{c}0.01 \\
(0.44)\end{array}$ \\
\hline \multicolumn{7}{|l|}{ R-squared } \\
\hline $\begin{array}{r}\text { within } \\
\text { between } \\
\text { overall }\end{array}$ & $\begin{array}{l}0.456 \\
0.009 \\
0.440 \\
\end{array}$ & $\begin{array}{l}0.444 \\
0.013 \\
0.431 \\
\end{array}$ & $\begin{array}{l}0.456 \\
0.009 \\
0.440 \\
\end{array}$ & $\begin{array}{l}0.406 \\
0.015 \\
0.389 \\
\end{array}$ & $\begin{array}{l}0.404 \\
0.012 \\
0.388 \\
\end{array}$ & $\begin{array}{c}0.406 \\
0.014 \\
0.39 \\
\end{array}$ \\
\hline $\begin{array}{l}\text { Number of observation } \\
\text { Number of groups }\end{array}$ & $\begin{array}{c}557 \\
20\end{array}$ & $\begin{array}{c}557 \\
20\end{array}$ & $\begin{array}{c}557 \\
20\end{array}$ & $\begin{array}{c}548 \\
20\end{array}$ & $\begin{array}{c}548 \\
20\end{array}$ & $\begin{array}{c}548 \\
20\end{array}$ \\
\hline
\end{tabular}

Absolute values of robust z-statistics are reported in parentheses. *** significant at $1 \%$; $* *$ significant at $5 \%$; * significant at $10 \%$. 